http://revped.ise.ro

\title{
THE LESSON OF LITERATURE AND ICT. THE MENTIMETER APPLICATION
}

\author{
MENTIMETER ŞI LECŢIA DE LIMBA ŞI LITERATURA ROMÂNĂ
}

\section{Mihaela STANCIU}

\author{
Journal of Pedagogy, 2019 (1), 139 - 160 \\ https://doi.org/10.26755/RevPed/2019.1/139
}

The online version of this article can be found at: http://revped.ise.ro/category/2019-en/

\section{(c) (1) (8)(2)}

This work is licensed under the Creative Commons Attribution-NonCommercial-ShareAlike 4.0 International License. To view a copy of this license, visit http://creativecommons.org/licenses/by-nc-sa/4.0/ or send a letter to Creative Commons, PO Box 1866, Mountain View, CA 94042, USA.

Published by:

\section{INSTITUTUL DE ȘTIINȚE ALE EDUCAȚIEI}

http://www.ise.ro/

Further information about Revista de Pedagogie - Journal of Pedagogy can be found at:

Editorial Policy: http://revped.ise.ro/editorial-policy/

Author Guidelines: http://revped.ise.ro/the-writer-guide-2/ 


\title{
MENTIMETER ŞI LEC IA DE LIMBA ŞI LITERATURA ROMÂNĂ
}

\author{
Mihaela Stanciu* \\ Liceul Teoretic „Stefan Odobleja”, \\ Bucureşti, România \\ mihaelateacher@yahoo.com
}

\section{Rezumat}

Diferen ele între genera ii se observă din ce în ce mai mult în şcoli, nu numai din punctul de vedere al mentalită ilor, ci şi din perspectiva evolu iei tehnologiei. În prezent, şcoala trebuie să se adapteze ritmului de dezvoltare a societă ii şi să răspundă nevoilor de formare a tinerilor, care vor deveni adul i într-o lume a viitorului, caracterizată de schimbare, de prezen a în via a de zi cu zi a tehnologiilor avansate şi a ştiin ei.

Întrebarea pe care ne-o punem, în calitate de profesori de limba şi literatura română, este în ce fel metodele şi instrumentele de lucru utilizate la clasă pot fi adaptate la noile mijloace de comunicare, astfel încât interac iunea profesor-elev să fie realizată într-o manieră mai constructivă şi mai motivantă.

Propunem în acest articol o nouă pistă de reflec ie pentru profesorii interesa i de optimizarea strategiilor de predare, aplica ia Mentimeter, un element de noutate în România, însă folosită în mod curent în Regatul Unit, în timpul cursurilor preuniversitare şi universitare. Vom avea în vedere definirea conceptului, modul de utilizare, mijloacele materiale necesare, modul de realizare a unor sarcini de lucru cu eviden ierea rolurilor profesorului şi ale elevului, realizarea unei aplica ii didactice.

În opinia noastră, Mentimeter poate fi un instrument TIC pus în serviciul educa iei, reuşita acestui demers depinzând însă, în bună măsură, de creativitatea şi deschiderea spre nou a fiecărui cadru didactic.

Cuvinte-cheie: aplica ie didactică, lec ia de literatură, Mentimeter, optimizarea metodelor şi instrumentelor de lucru, schimbarea societă ii.

* Profesor drd., Liceul Teoretic „Ştefan Odobleja”, Bucureşti, România. 


\section{Abstract}

Progressively, the differences between generations can be observed in schools, not only from the mentality point of view, but also through the evolution of technology. Nowadays, school has to adapt to the society's development rhythm and prepare the youth for the future, which is characterized by change, advanced technology and science.

As a Romanian Literature and Language teacher, the question which is raised is in what way the strategies, methods, and means used in class can be updated to the new types of communication and the necessities that students have according to the fundamental change of the society, such that the connection teacher-student can be realised in a more constructive and motivational way.

This article proposes a new way of reflection for teachers interested in the optimization of methods and teaching means used in class-Mentimeter represents an innovative element in Romania, but currently used in the United Kingdom for high-school classes and university lectures. We will take into consideration how to define this concept, the process, the necessary means and materials, the lesson category, how to give suitable tasks in order to highlight the teacher's and student's role, realising didactic applications.

In our opinion, Mentimeter can be an ICT method used in education, but it's success depends on the teachers' creativity and open-mindedness to innovation.

Keywords: didactic application, literature lesson, methods and means optimization, Mentimeter, society change.

\section{Introducere}

„, Şcoala oricând este o închisoare, când învă ătorul va fi mărginit, oricând o grădină, când acesta va fi un om de spirit, care va şti să intereseze pe elevii săi şi obiectul ce propune. Obiectul e cu totul indiferent, metoda de predare-lucrul de căpetenie." Mihai Eminescu ${ }^{1}$

Analizând vârsta popula iei aflate în circuitul educa ional, se observă că, în prezent, elevii înscrişi la şcoală sunt născu i în secolul XXI, în timp ce profesorii lor sunt născu i în secolul precedent. În cursul acestor decenii, societatea a trecut prin diferite transformări, vizibile, în primul rând, în echipamentele electronice pe care le folosim în via a de zi cu zi, precum computerele şi smartphone-urile, aplica ii ale nanotehnologiei. 
Contribu ia tehnologiei avansate face ca paradigma educa iei să se modeleze continuu, potrivit progresului, idealurilor şi concep iei societă ii despre viitor, prin care aceasta caută să le pună în operă pentru a supravie ui. Neelie Kroes, vicepreşedintele Comisiei Europene şi comisarul pentru Agenda Digitală pentru Europa afirma că, azi, ,ne confruntăm cu mult mai mult decât o tehnologie nouă: vorbim despre o schimbare fundamentală a societă ii şi a interac iunii umane. Iar pentru a fi siguri că profităm de asta la maximum şi pentru a ne asigura că to i cetă enii beneficiază de asta, trebuie să investim în capitalul şi competen ele umane" (Constantinescu \& Dănăilă, 2013).

Având în vedere premisele de mai sus, studiul de fa ă descrie, sub forma unui cvasiexperiment didactic realizat de noi, utilizarea Sistemului de răspuns Mentimeter în lec ia de limba şi literatura română, la două clase de la o şcoală din Bucureşti. În cadrul aplicării unor tehnici de învă are interactivă, elevii au utilizat smartphone-ul şi internetul pentru chestionare scurte, în activitatea curentă la clasă, în al doilea semestru al anului şcolar 2018-2019, pe o temă comună: „Romanul”.

Scopul cercetării noastre este de a identifica care sunt acele aplica ii ale tehnologiilor, utilizate curent în practica şcolară modernă, care să transforme folosirea necorespunzătoare a smartphone-ului de către elevi sau ca distragere a aten iei în timpul orei de curs, într-o oportunitate menită să servească studiului, optimizând strategiile didactice de predare-învă are si evaluare.

Obiectivele centrale ale cercetării le-au constituit organizarea unor activită i didactice, utilizând Sistemul de răspuns Mentimeter, şi studierea modului în care acest tip de interac iune îmbunătă eşte motivarea în lec ie. Întrebarea specifică căreia a încercat să-i răspundă cercetarea noastră a fost dacă poate fi integrată, adaptată şi utilizată, în lec ia de limbă şi literatură, la nivel gimnazial şi liceal, aplica ia Mentimeter. Am investigat, de asemenea, ce fel de sarcini de lucru sunt adaptabile sistemului de răspuns Mentimeter, care sunt, în acest context pedagogic, rolurile profesorului şi ale elevului, încercând să în elegem avantajele şi limitele Mentimeter, având în vedere specificul lec iei de limbă şi literatură română. 
Analiza datelor colectate calitativ, pe baza unei scurte anchete pe bază de chestionar, a validat beneficiile acestui tip de interac iune în lec ie, sub rezerva că eşantionul mic de aplicare nu permite generalizarea datelor, ci oferă doar o pistă de reflec ie şi cercetare pentru profesorii interesa i să-şi optimizeze strategiile de lucru cu elevii.

\section{Cercetări în domeniu. Scurtă privire de tip investigativ}

Într-o succintă descriere a mijloacelor de învă ământ, pe genera ii (Ionescu, Bocoş, 2009; Cristea, 2000) tabla, manuscrisele (I), manualele, textele imprimate (II), mijloacele audio-vizuale (III), maşinile de instruire (IV), computerul (V), se observă că emi ătorul portabil se înscrie în categoria mijloacelor de învă ământ din genera ia a VI-a, din cadrul tehnologiei informa iei şi comunicării.

Fără a considera tehnologia exclusiv un panaceu universal sau a ignora părerile acelora care spun elevilor să închidă mobilele în timpul orelor de curs, credem că, fructificat cu măiestrie de către profesori în cadrul unei aplica ii software, smartphone-ul se poate transforma într-un instrument util procesului de învă ământ. Mai mult, nu presupune alte costuri de dotare institu ională, ceea ce devine un beneficiu pentru procesul instructiv-educativ, aspect care nu ar trebui neglijat.

În urma unei incursiuni on-line, am constatat că în practica curentă de predare universitară şi preuniversitară din Regatul Unit există mai multe aplica ii software, utilizate de mul i ani, ca mijloace interactive de sondaj. Denumite şi sisteme de răspuns ale clasei, Mentimeter, Poll Everywhere, Socrative, SMART Response System (Clarke, 2017), acestea operează on-line, folosind dispozitive mobile, în cele mai multe cazuri, smartphone-ul. Ele sunt softuri de tip ,clicker” (Bojinova \& Oigara, 2013), ce func ionează doar cu ajutorul unui telefon şi al unei conexiuni la internet, elemente de care dispun mul i elevi şi studen i din majoritatea liceelor şi facultă ilor din România.

Sistemele clicker, care facilitează activită i de predare (Bruff, 2009), sunt foarte populare în învă ământul universitar occidental. Ele se înscriu în filozofia potrivit căreia secretul educa iei este de a în elege care este nivelul 
audien ei, de a ine seama foarte bine de ce ştiu şi ce nu ştiu elevii, aşa cum afirma într-un interviu prof. Mark Hersam ${ }^{2}$ de la Universitatea Northwestern. Cercetările în domeniu au arătat că marele beneficiu al elevilor, în procesul de învă are, este atunci când aceştia sunt angaja i activ (Bloom, 1984). Potrivit lui Guthrie şi Karlin (2004), elevii sec. XXI sunt, în primul rând, activi. Tehnologia de tip clicker oferă o abordare pentru profesorii care doresc să implice to i elevii în învă area activă în clasă. Johnson (2005) a descris cum clickerii au ajutat profesorii prin angajarea activă a elevilor în timpul întregii ore, furnizându-le feedback prompt. Sistemul de răspuns public precum Mentimeter creează cadrul optim pentru interac iunea profesor-elevi, transformând clasa dintr-un public majoritar pasiv, într-unul care este activ, prin simpla adresare a unei întrebări la care trebuie să răspundă întregul colectiv. Folosindu-şi telefoanele, elevii pot să reflecteze asupra conceptului predat şi să răspundă la întrebări cu alegere multiplă. Mentimeter este un sistem prin care audien a poate răspunde (lucrurile de bază pe care le poate face aplica ia sunt oferite gratuit) şi combină hardware-ul wireless cu prezentarea software (Rudolph, 2018). Într-un context educa ional, sistemul de răspuns Mentimeter este de tipul cloud-based şi open-source, iar elevii îşi pot aduce propriile dispozitive precum smartphone-urile, tabletele, laptop-urile pentru a folosi, în clasă, acest sistem.

Pentru participan i, sistemul oferă posibilitatea de a răspunde la o întrebare, privind un anume subiect. Fiecare posesor al unui dispozitiv accesează întrebarea folosind internetul. Potrivit op iunii profesorului, sistemul opreşte „,votarea” pentru întrebarea respectivă şi face clasificarea răspunsurilor. În general, rezultatele pot fi vizibile instantaneu pe videoproiector. În prezent, sistemul de răspuns pentru audien ă poate fi un simplu produs software, hardware-ul fiind adus de către utilizatori, astfel reducându-se vizibil costul pentru institu ie, iar dacă este folosită o versiune gratuită, atunci costul este zero.

Mentimeter reprezintă un mod simplu de interac iune între audien ă şi cel care transmite informa ia, fiind utilizat în domenii diverse, în timpul cursurilor, al workshop-urilor sau al întâlnirilor de afaceri.

În învă ământul universitar şi preuniversitar din Marea Britanie, Mentimeter este un instrument de sondaj şi colaborare foarte popular, ce furnizează 
feedback, instant, în timpul lec iei (de exemplu, se foloseşte, în mod curent, la Imperial College London, potrivit men iunilor existente pe site-ul acestei universită i). El permite utilizatorilor să creeze un mediu de învă are interactivă prin interogarea elevului în timp real, pe parcursul cursurilor, şi de a vedea rezultatele învă ării.

Metoda se foloseşte zilnic, în special la disciplinele exacte. Întrebările se pot pune în orice moment al cursului, la început, pe parcurs sau la final, cu o frecven ă variabilă, în func ie de necesită ile profesorului. Ora capătă astfel atributele unei comunicări depline profesor-elevi, fiindcă îi face pe elevi să participe mult mai mult decât în mod obişnuit, to i fiind implica i, spre deosebire de o oră obişnuită de curs în care, utilizând metoda dialogului socratic, nu este posibil să fie implica i to i în lec ie. Practic, elevii sunt antrena i să răspundă la întrebarea profesorului, iar acesta poate vedea, statistic, câ i au în eles şi câ i nu. Afişajul numeric efectiv oferă posibilitatea profesorului de a observa precis câ i elevi au ales răspunsul corect. Mai mult, şi ei văd asta, ceea ce înseamnă că se cunoaşte realitatea de către to i partenerii educa ionali, conştientizându-se nevoile educa ionale ale momentului lec iei la care s-a ajuns.

În vederea pregătirii unei lec ii, profesorul creează întrebări diferite. Mentimeter oferă mai multe tipuri de întrebări: alegere multiplă; scala Likert; open-ended, când elevii completează/redactează răspunsul; 100 de puncte, participan ii pot distribui 100 de puncte răspunsurilor alternative; participan ii pot evalua itemii în două dimensiuni şi ,cine-va-câştiga”.

Datele aplica iei pot fi colectate anonim sau pot fi salvate pentru o analiză, în scopuri comparative şi de cercetare educa ională, rezultatele pot fi exportate în Excel. Există beneficii adi ionale ale sistemului de răspuns pentru audien ă şi acestea sunt raportate şi discutate în mediul academic. Realizatorii aplica iei afirmă că vizualizarea răspunsurilor îi face pe elevi să reflecteze şi apoi să poarte o discu ie din acel punct împreună cu profesorul. Cu Mentimeter, fiecare are posibilitatea de a-şi exprima opinia, fără a fi afectat de altă persoană prezentă în încăpere. Mentimeter îi face pe elevi să interac ioneze într-o manieră inovativă. Ei se pot deschide şi le pot spune şi celorlal i perspectiva lor, astfel încât to i se simt implica i, iar interac iunea creează o discu ie constructivă. 


\section{Metodologie}

Aflându-ne în faza preexperimentală, demersul pedagogic s-a desfăşurat la două clase din încadrare, clasa a VIII-a şi clasa a XI-a. Clasa a VIII-a este o clasă omogenă din punctul de vedere al rezultatelor la învă ătură, cu un nivel mediu în pregătirea şcolară, ob inând media 7,45 la teza la Limba şi literatura română a semestrului I. Clasa a XI-a se caracterizează printr-o structură eterogenă, corespunzătoare unei activită i şcolare cu rezultate de la foarte slabe la bune (media 5,50 pe semestrul I). În general, clasa prezintă dificultă i la învă ătură şi disciplină, acesta fiind un motiv al alegerii ei pentru cvasiexperiment. $\mathrm{Nu}$ am organizat clase de control, urmând ca rezultatele să fie comparate cu evolu ia claselor înseşi, de la o etapă la alta. Elevii celor două clase au utilizat smartphone-ul în rezolvarea unor teste cu mai multe tipuri de itemi (alegere multiplă, adevărat sau fals) în activitatea curentă de la clasă, care au acoperit con inuturile lec iei („Romanul”), testele aplicându-se pe parcursul a trei săptămâni consecutive (Figurile nr. 1-3). Numărul total al participan ilor a fost de 58, 28 la clasa a VIII-a şi 30 la clasa a XI-a.

\begin{tabular}{|c|c|c|c|c|c|c|c|c|}
\hline 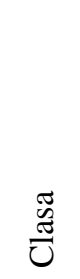 & $\frac{\frac{D}{0}}{\frac{\pi}{0}}$ & 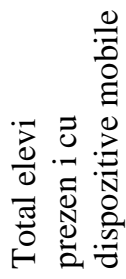 & 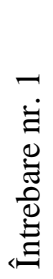 & 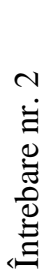 & 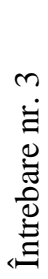 & 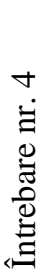 & $\begin{array}{l}n \\
\dot{\Xi} \\
0 \\
\stackrel{\Xi}{\Xi} \\
\stackrel{0}{\Xi} \\
\stackrel{\Xi}{\Xi}\end{array}$ & 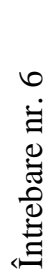 \\
\hline VIII & 28 & 28 & 28 & 28 & 28 & 28 & 28 & 28 \\
\hline XI & 30 & 20 & 19 & 19 & 20 & 19 & 18 & 19 \\
\hline Total & 58 & 48 & 47 & 47 & 48 & 47 & 46 & 47 \\
\hline
\end{tabular}

Tabelul nr. 1. - Sarcina de lucru nr. 1 


\begin{tabular}{|c|c|c|c|c|c|c|c|c|c|c|c|c|c|}
\hline$\frac{\mathbb{J}}{\tilde{U}}$ & $\frac{\frac{3}{0}}{\frac{\pi}{0}}$ & 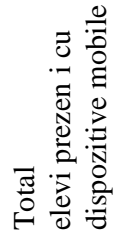 & 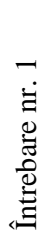 & 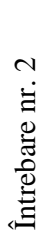 & 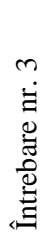 & 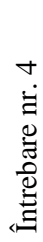 & 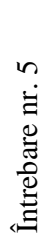 & 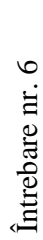 & 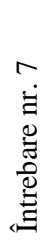 & 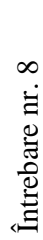 & 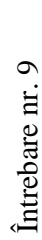 & 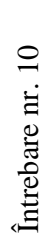 & 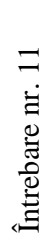 \\
\hline XI & 30 & 16 & 12 & 14 & 15 & 16 & 16 & 15 & 16 & 16 & 15 & 16 & 15 \\
\hline
\end{tabular}

Tabelul nr. 2. - Sarcina de lucru nr. 2

\begin{tabular}{|c|c|c|c|c|c|c|c|}
\hline$\frac{\tilde{J}}{\tilde{U}}$ & 党 & 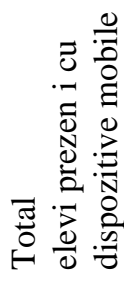 & 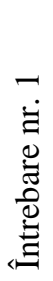 & 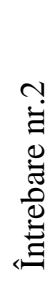 & 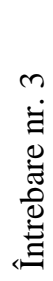 & 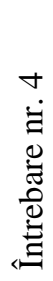 & 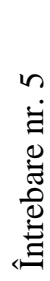 \\
\hline XI & 30 & 16 & 16 & 16 & 15 & 14 & 13 \\
\hline
\end{tabular}

Tabelul nr. 3. - Sarcina de lucru nr. 3

\section{Prezentarea şi explicarea aplica iei didactice experimentate}

\subsection{Problematica şi identificarea nevoilor}

Analizând contextul şcolar cotidian, se observă că majoritatea popula iei şcolare de ine astăzi telefoane inteligente pe care le foloseşte în mod curent. Interesul elevilor pentru smartphone, în timpul orei, poate deveni însă stânjenitor pentru profesor, care trebuie să facă fa ă concuren ei multitudinilor de tenta ii disponibile pe internet (Snapchat, Instagram, Twitter etc.). Apare problema câştigării bătăliei aten iei elevilor pe care profesorul 
trebuie să o ducă în fiecare clipă, pe parcursul unei lec ii. Solu ia o reprezintă, după părerea noastră, utilizarea unor strategii didactice care să includă acele metode, tehnici şi mijloace ce trebuie să rezoneze cu sfera de interes a elevilor. Noi vedem tehnologia ca un facilitator al bunelor practici în procesul de predare şi învă are şi, de aceea, ne preocupă în ce fel metodele şi instrumentele de lucru utilizate la clasă pot fi adaptate la noile mijloace de comunicare, astfel încât interac iunea profesor - elev să fie realizată într-o manieră mai constructivă şi mai motivantă. Demersul nostru se înscrie într-un cadru cvasiexperimental şi natural al cercetării care îşi propune să verifice următoarea ipoteză de lucru:

Dacă în ora de limba şi literatura română se utilizează sistemul de răspuns Mentimeter, atunci ne putem aştepta la o îmbunătă ire a performan elor elevilor şi la o creştere a motiva iei pentru studiu. Alături de variabila independentă a cercetării, sistemul de răspuns Mentimeter, am re inut câteva variabile dependente ce in de stilul didactic, particularită ile elevilor, cât şi variabile de context, referitoare la spa iul şcolar şi resursele materiale, deoarece profesorul trebuie să aibă acces la o sală de clasă dotată cu computer, videoproiector, ecran de proiec ie, internet, iar elevii trebuie să de ină un telefon conectat la internet.

\subsection{Procedură. Mentimeter în lec ia de literatură}

Înainte de aplica ia didactică propriu-zisă, profesorul trebuie să-şi creeze un cont pe site-ul www.mentimeter.com, pentru înregistrare. Apoi, concepe setul de întrebări adecvate obiectivelor lec iei. În timpul orei, se conectează la aplica ia didactică creată şi le comunică elevilor codul care să le permită accesul, prin telefon, la sarcinile de lucru. După un timp de reflec ie, elevii trimit răspunsul, alegând varianta pe care o consideră corectă. Profesorul vizualizează statistica răspunsurilor. Urmează discu ii în care profesorul justifică răspunsurile corecte şi constată, procentual, câ i elevi şi-au însuşit no iunile predate. Elevii scriu răspunsurile complete pe caiete. În final, profesorul permite vizualizarea răspunsurilor, pentru to i elevii, pe ecran.

Cea mai mare parte a aplica iei noastre didactice a fost îndreptată, cu precădere, spre crearea unor situa ii care să determine o mai mare implicare a elevului, stimulând interesul pentru lec ie şi interactivitatea. 
Activitatea a început cu familiarizarea elevilor privind modalitatea de utilizare a telefonului în oră, prin intermediul aplica iei Mentimeter. Foarte repede, elevii au învă at cum să se logheze la aplica ie pe baza unui cod de utilizare. Cei care nu au avut telefon sau internet au lucrat în echipă cu colegul de bancă, selectând împreună răspunsul la întrebare. La clasele de gimnaziu şi liceu, am optat pentru itemi cu alegere multiplă sau de tipul adevărat sau fals, care corespund unei variante de bacalaureat de tip grilă, subiectele I şi II, respectiv modelului de evaluare na ională. Sarcinile de lucru au fost prezentate şi pe ecran cu ajutorul unui retroproiector, apoi elevii şi-au exprimat, rând pe rând, op iunile. Am analizat răspunsurile elevilor, urmărind statistica afişată de aplica ia Mentimeter şi, apoi, am prezentat într-o discu ie amplă la nivelul întregii clase, varianta de răspuns corectă, justificând şi scriind la tablă rezolvarea completă.

\subsubsection{Cărui model de lec ie îi este adecvat sistemul de răspuns} Mentimeter?

Acest demers pedagogic a presupus identificarea tipului de lec ie corespunzător aplica iei, precum şi a rolului profesorului şi al elevilor.

Aplica ia Mentimeter este adecvată, în special, modelului de lec ie tehnocentric, fundamentat pe teoria neobehavioristă (Neacşu, 2015), cea a cooperării operante a lui B.F. Skinner, înso ită cu unele elemente de feedback, ulterior primind un puternic impuls din partea teoriei informa iei, asociată cu valen ele experimentelor de instruire programată.

Aten ia noastră a fost orientată în direc ia ,taylorizării” instruirii, a descompunerii actului de învă are-predare în opera ii ce vor fi dispuse într-o ordine optimă. Este un model de lec ie care conduce la îmbunătă irea performan elor elevului şi ale profesorului, fiind centrat pe coac iune.

Lec ia propriu-zisă presupune analiza, planificarea, identificarea constrângerilor, care pornesc de la întrebările: Care sunt obiectivele vizate? Care sunt actorii implica i (numărul, vârsta, dotarea tehnică etc.)? Care sunt noile şi diversele nevoi ale educabililor? Care sunt aşteptările şi motiva iile colective şi individuale, în raport cu standardele programei şcolare? 


\subsubsection{Rolurile profesorului - contextualizare explicită}

În principiu, putem vorbi despre gestionarea mai multor roluri ale profesorului, care presupun alocarea unui număr mare de ore pentru conceperea şi integrarea întrebărilor în cadrul aplica iei: definirea opera ională a obiectivelor; analiza riguroasă a con inuturilor învă ării şi a dificultă ilor pe care le prezintă; fragmentarea optimă a materiei şi organizarea sistematică a opera iilor de învă are deduse din analiza amintită; tehnicizarea metodelor aplicate prin recurgerea la mijloacele de învă ământ de tip digital; evaluarea atentă a eficien ei învă ării, bazată pe aplicarea unui control al rezultatelor performan elor cu ajutorul unor instrumente de măsurare bine puse la punct; recursul frecvent la feedback adecvat opera iilor implicate în vederea reglării şi autoreglării continue a conexiunilor predării cu învă area; crearea de itemi cu răspunsuri de tip grilă, care vizează stăpânirea conceptelor predate şi aplicarea acestora prin crearea de situa ii de învă are creativă, nu numai algoritmizată; culegerea datelor şi analiza lor; punerea elevului în ac iune, coresponsabilizarea fa ă de calitatea eforturilor şi a cunoştin elor sale.

\subsubsection{Care sunt rolurile elevului?}

La rândul lui, elevul trebuie să se angajeze în rezolvarea sarcinii de lucru, efectuând exerci ii şi construindu-şi astfel propria în elegere asupra conceptelor învă ării. De asemenea, prin vizualizarea răspunsurilor organizate statistic, conştientizează propriul demers de învă are, rezultatele, neajunsurile, îşi perfec ionează continuu tehnica de rezolvare, devenind activ în desfăşurarea lec iei.

\subsubsection{Aplica ie specială}

Un model comparativ opera ional cu sarcinile de lucru pentru subiectele I şi II, bacalaureat, modelate după varianta grilă (Sandu, 2002).

Derularea concretă a aplica iei o vom reproduce mai jos, pentru a se putea observa cum itemii propuşi şi răspunsurile elevilor sunt transpuse în 
statisticile furnizate de aplica ie. Men ionăm că textul-suport selectat din romanul „Baltagul” de Mihail Sadoveanu nu a mai fost reprodus, din economie de spa iu.

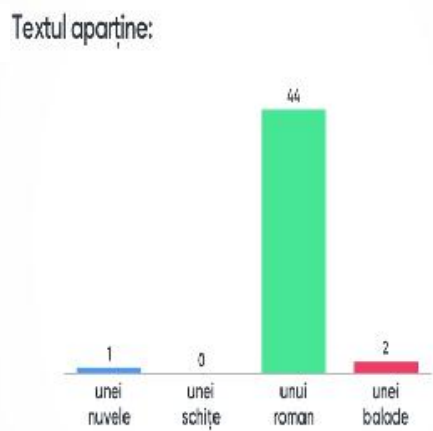

ovasineser Textul apartine genuluil:

DNerimaty

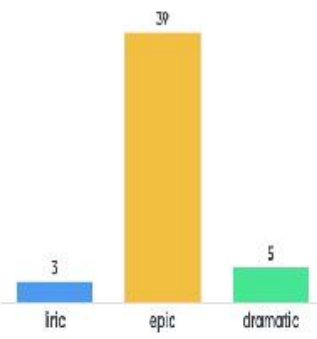

47

Modurile de expunere folosite in textul anterior sunt:

sunteres

Timpul verbelor naratiunii este:
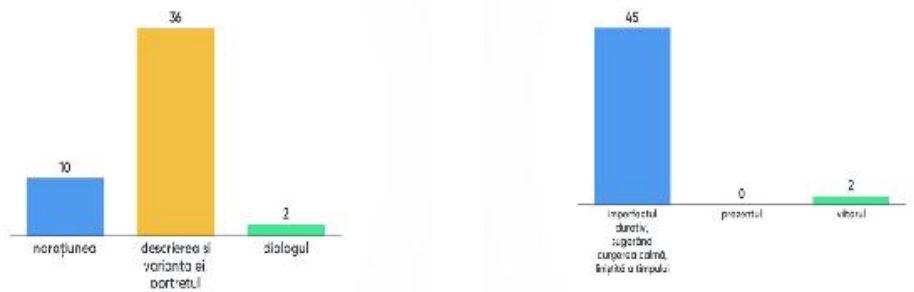

Gerunzille "stând" și "torcônd":

anosinater

În fragmentul citat, personajul Vitcrio Lipan este caracterizat direct:
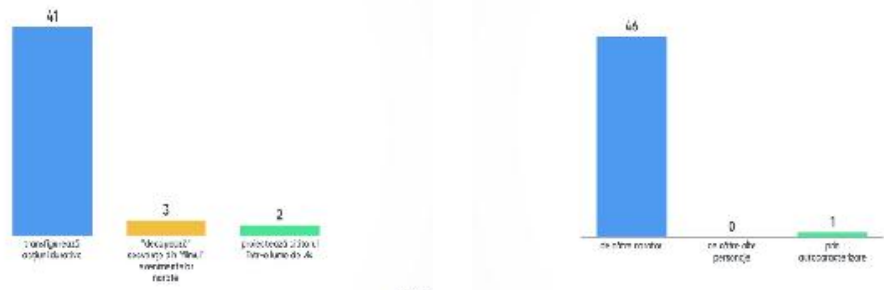

Figura nr. 1. Sarcina de lucru nr. 1 (clasele a VIII-a şi a XI-a) 
1. Sensul substantivului crâmpei, din text, este:

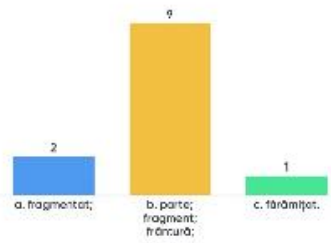

3. Rolul cratimei în fiecore dintre secvențele să-I văd; să-I ierte este explicat corect, în ordine, în seric:

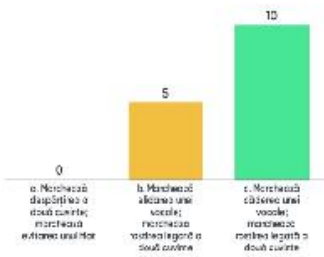

5. In secvența, Ochi ei oăprii, in oare parcó se răstrưngea lumino oastanie a pärului, erou duși departe", existâ, ho ordine:

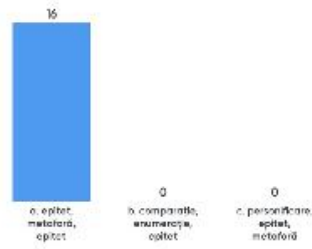

7. Dimensiunea temporală a desfășurăril scenel date este conturată prin structurile lexicale:

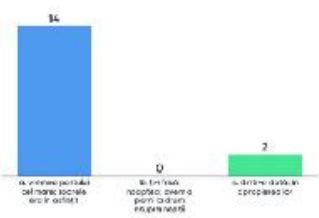

amoraratur 2. Sensul adjectivului rituală este:

asovencter
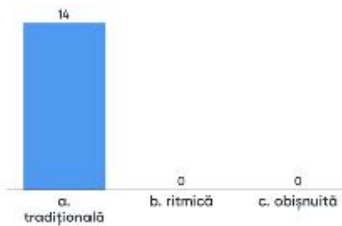

412

ansertinear

4.Mărcile lexico-gramaticale ale naratorului omniscient, în acest text, sunt:
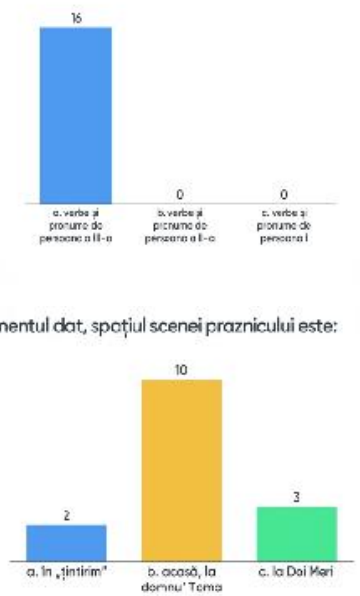

a 16

8. Obiectivul Vitoriei este:

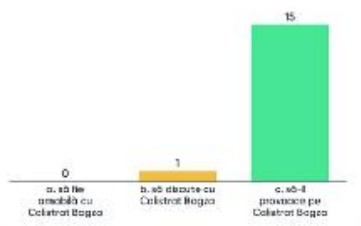

Figura nr. 2. Sarcina de lucru nr. 2 (clasa a XI-a) 
(urmare din pagina precedentă)

9. Două motive literare prezente in fragmentul dat sunt:

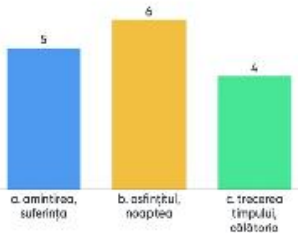

a wordincer 10. Situatiilo, everimentele sau faptele petrecute, in ordine, în scena de mai sus sunt:

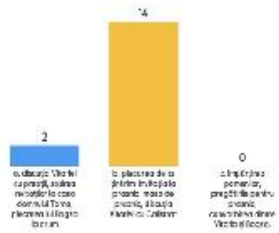

11. Relația dintre Vitoria și Bogza este:

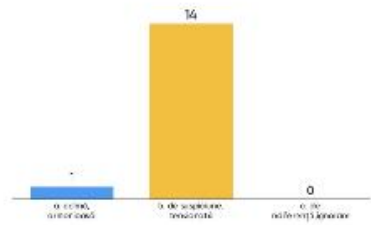

nunentmoter

\& 15

Figura nr. 2. Sarcina de lucru nr. 2 (clasa a XI-a)

1AFTema textului „Baltagul” este călătoria. Ourtiment 2AF Cuvârtul sfialã este folosit cu sens denototiv.

a4atrexs

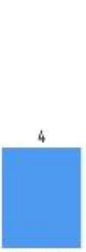

Adevărot

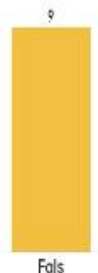

Fols

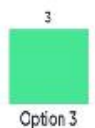

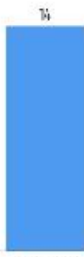

Adevárot

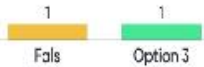




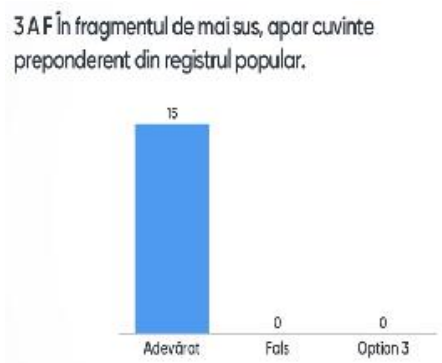

Duerdmes 4 AF Fragmentul de text apartine unui roman

E wertinxts interbelic de tip balzacian.

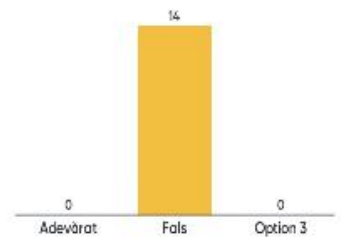
pentru Vitoria contactul cu novo civilizație este cifici.

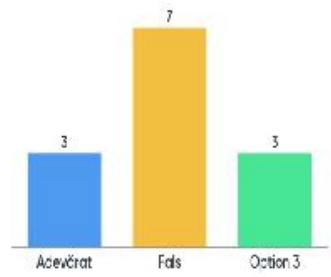

Figura nr. 3. Sarcina de lucru nr. 3 (clasa a XI-a)

\section{Ce am descoperit? Prezentarea rezultatelor}

Pentru a estima impactul Mentimeter în lec ie, am aplicat ancheta pe bază de chestionar (după modelul Bojinova, Oigara, 2013) şi am folosit metoda observării calitative concretizată în notele cercetătorului şi în analiza slide-urilor şi a prezentărilor ob inute prin aplica ie. 


\begin{tabular}{|c|c|c|c|c|c|c|c|}
\hline & & & 1 & 2 & 3 & 4 & 5 \\
\hline $\begin{array}{l}\text { Nr. } \\
\text { crt. }\end{array}$ & Întrebare & $\begin{array}{l}\text { Total } \\
\text { elevi }\end{array}$ & 뮴 & 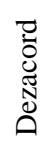 & $\underset{\Xi}{Z}$ & 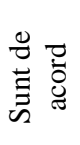 & 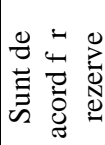 \\
\hline 1 & $\begin{array}{l}\text { În general sunt satisfăcut cu } \\
\text { utilizarea aplica iei Mentimeter }\end{array}$ & 58 & - & - & 2 & 10 & 46 \\
\hline 2 & $\begin{array}{l}\text { Aplica ia Mentimeter a făcut } \\
\text { ora mai atractivă comparativ cu } \\
\text { orele tradi ionale }\end{array}$ & 58 & - & - & 1 & 8 & 49 \\
\hline 3 & $\begin{array}{l}\text { Utilizarea aplica iei Mentimeter } \\
\text { a îmbunătă it gradul meu de } \\
\text { implicare în desfăşurarea } \\
\text { cursului }\end{array}$ & 58 & - & - & 3 & 7 & 48 \\
\hline 4 & $\begin{array}{l}\text { Distribuirea răspunsurilor clasei } \\
\text { ajută la creşterea încrederii mele }\end{array}$ & 58 & - & - & 0 & 11 & 47 \\
\hline 5 & $\begin{array}{l}\text { Discu iile cu colegii mă ajută să } \\
\text { in eleg mai bine materia predată }\end{array}$ & 58 & - & - & 0 & 4 & 54 \\
\hline 6 & $\begin{array}{l}\text { Feed-back-ul imediat al } \\
\text { profesorului m-a ajutat să } \\
\text { în eleg conceptele }\end{array}$ & 58 & - & - & 0 & 3 & 55 \\
\hline 7 & $\begin{array}{l}\text { Îmi place mai mult să particip în } \\
\text { clasă cu aplica ia Mentimeter } \\
\text { comparativ cu ridicarea mâinii } \\
\text { şi doresc să lucrez în continuare }\end{array}$ & 58 & - & - & 0 & 9 & 49 \\
\hline 8 & $\begin{array}{l}\text { Utilizarea aplica iei Mentimeter } \\
\text { m-a motivat să studiez mai mult }\end{array}$ & 58 & - & - & 1 & 4 & 53 \\
\hline 9 & $\begin{array}{l}\text { Aplica ia Mentimeter m-a ajutat } \\
\text { să în eleg subiectele materiei } \\
\text { predate }\end{array}$ & 58 & - & - & 0 & 5 & 53 \\
\hline 10 & $\begin{array}{l}\text { M-am sim it mai angajat în } \\
\text { munca din clasă }\end{array}$ & 58 & - & - & 2 & 6 & 50 \\
\hline
\end{tabular}

Tabelul nr. 4. - Centralizator chestionare din cadrul anchetei 


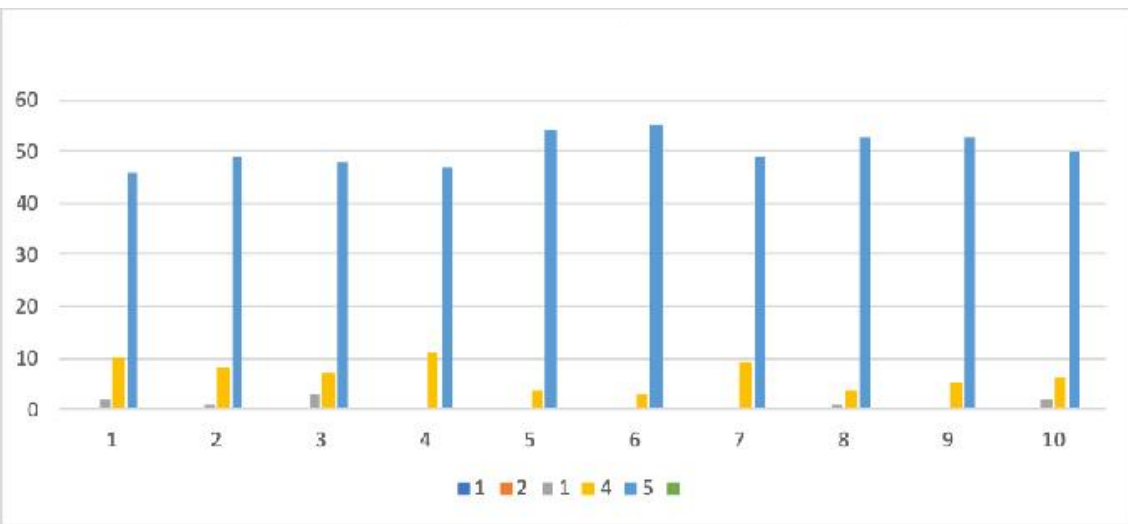

Figura nr. 4. - Diagramă numerică - răspunsuri chestionar

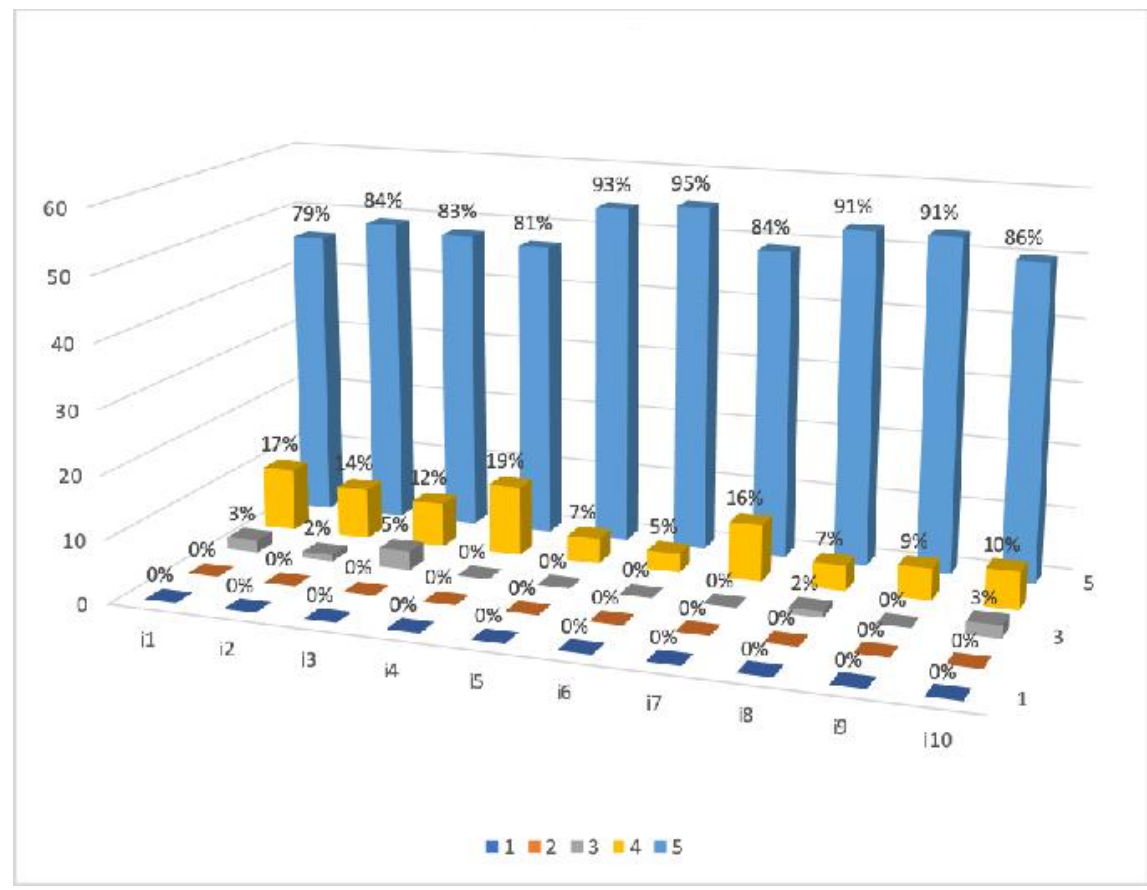

Figura nr. 5. - Diagramă procentuală - răspunsuri chestionar 


\begin{tabular}{|c|c|c|c|c|c|}
\hline Scala & 1 & 2 & 3 & 4 & 5 \\
\hline Întrebări & $\begin{array}{c}\text { Dezacord } \\
\text { total }\end{array}$ & Dezacord & Neutru & $\begin{array}{c}\text { Sunt de } \\
\text { acord }\end{array}$ & $\begin{array}{l}\text { Sunt de acord } \\
\text { fără rezerve }\end{array}$ \\
\hline 1 & $0 \%$ & $0 \%$ & $3 \%$ & $17 \%$ & $79 \%$ \\
\hline 2 & $0 \%$ & $0 \%$ & $2 \%$ & $14 \%$ & $84 \%$ \\
\hline 3 & $0 \%$ & $0 \%$ & $5 \%$ & $12 \%$ & $83 \%$ \\
\hline 4 & $0 \%$ & $0 \%$ & $0 \%$ & $19 \%$ & $81 \%$ \\
\hline 5 & $0 \%$ & $0 \%$ & $0 \%$ & $7 \%$ & $93 \%$ \\
\hline 6 & $0 \%$ & $0 \%$ & $0 \%$ & $5 \%$ & $95 \%$ \\
\hline 7 & $0 \%$ & $0 \%$ & $0 \%$ & $16 \%$ & $84 \%$ \\
\hline 8 & $0 \%$ & $0 \%$ & $2 \%$ & $7 \%$ & $91 \%$ \\
\hline 9 & $0 \%$ & $0 \%$ & $0 \%$ & $9 \%$ & $91 \%$ \\
\hline 10 & $0 \%$ & $0 \%$ & $3 \%$ & $10 \%$ & $86 \%$ \\
\hline
\end{tabular}

Tabelul nr. 5. - Tabel corespondent al diagramei procentuale

Rezultatele arată că utilizarea aplica iei Mentimeter a avut un impact semnificativ şi pozitiv asupra elevilor atât din clasa de la gimnaziu, cât şi din clasa de la liceu.

Observa iile noastre comparative pun în eviden ă că în practica tradi ională, verificarea cunoştin elor este prima sau ultima parte a unei lec ii obişnuite/ mixte. Procedeul curent folosit stă în examinarea şi notarea a 3-4 elevi în 15-20 de minute sau, uneori, se adresează câteva întrebări şi celorlal i elevi ai clasei spre a-i determina să fie aten i la răspunsurile elevilor. Procedeul are numeroase neajunsuri: nu poate antrena to i elevii clasei într-o conlucrare activă; men ine îngrijorarea elevilor fa ă de verificare şi notare sau chiar îi determină la calcule privind data ascultării sau nota pe care trebuie să o ob ină; verificarea tradi ională contribuie, în măsură substan ială, la men inerea activită ii stereotipe de ascultare-predare; ea consumă o cantitate mare de timp (cel pu in o treime din timpul orei) cu un randament scăzut; euristica ce se practică la ascultare nu contribuie întotdeauna la învă area prin problematizare şi algoritmizare; se adaugă faptul că procedeul men ine rela ii încordate, deseori conflictuale între profesori şi elevi şi cultivă interesul mai mult pentru notă decât pentru învă are. 
Referitor la sistemul de răspuns Mentimeter, discu iile cu elevii care au testat aplica ia Mentimeter şi scurta anchetă (figurile nr. 5-7) care a urmat, au indicat că elevii s-au sim it mai angaja i în activitatea din clasă $(86 \%)$ şi au beneficiat imediat de un feedback din partea profesorului (95\%), dorind să lucreze şi în continuare cu această aplica ie (84\%), care nu presupune o notare, ci doar un feedback care conduce la conştientizarea şi stimularea învă ării. De asemenea, profesorul a putut constata imediat lacunele elevilor la sfârşitul orei de curs, ceea ce a permis interven ia imediată pentru corijarea acestora şi formularea unor exerci ii viitoare care să permită consolidarea cunoştin elor. La teza din semestrul al doilea s-a constatat o îmbunătă ire a rezultatelor elevilor pentru clasa a VIII-a $(7,96)$ care nu este însă suficient de relevantă pentru studiul de fa ă, deoarece to $i$ au fost interesa i să înve e în vederea evaluării na ionale; clasa a XI-a nu a înregistrat o evolu ie semnificativă, men inând o constantă a mediei pe clasă.

În cadrul cvasiexperimentului didactic, s-a făcut constatarea că verificarea clasică orală a 3-4 elevi la fiecare lec ie consumă o mare cantitate de timp, rezultând o implicare redusă a elevilor, în timp ce prin aplica ia Mentimeter sunt implica i to i elevii, într-un timp efectiv de lucru care se derulează pe un interval de 3-5 minute, pe un număr de sarcini care pot varia de la 5 întrebări la 20.

\section{Concluzii preliminare, impact şi perspective aşteptate}

Aplica ia Mentimeter poate fi utilizată cu eficien ă şi uşurin ă în lec iile dedicate pregătirii examenelor de evaluare na ională şi bacalaureat.

Numărul elevilor care interac ionează este de $100 \%$ spre deosebire de situa ia clasică, când verificarea orală presupune antrenarea a doar câtorva elevi. Este, de asemenea, şi un câştig de timp, deoarece într-un interval foarte scurt se pot face mult mai multe exerci ii. $\mathrm{Nu}$ în ultimul rând, folosirea tehnologiei îi entuziasmează pe elevi şi le focalizează aten ia pe sarcini de lucru pe care trebuie să le rezolve în aşa fel încât să fie în pas cu întreaga clasă. De asemenea, nu au mai fost necesare costuri în ceea ce priveşte imprimarea fişelor de lucru. Acest studiu are şi limite impuse, în primul rând, de dotarea şcolii. Din cele două clase la care am folosit aplica ia 
Mentimeter, una nu avea internet, ceea ce a presupus deplasarea în cabinetul de chimie pentru accesul la internet şi videoproiector. De asemenea, am apelat, uneori, pentru accesul la internet şi la dispozitive personale. $\mathrm{Nu}$ to $\mathrm{i}$ elevii au telefon inteligent şi acces la internet.

Pe de altă parte, ar fi fost foarte bine pentru informare de a se ancheta elevii şi la începutul anului şcolar, nu numai în semestrul al doilea. Nivelul de dificultate a întrebărilor impune numărul acestora. Se pot formula trei-patru întrebări pe oră de dificultate mai mare sau aproximativ 20 de întrebări uşoare pentru a se în elege un anumit concept. $\mathrm{Cu}$ această aplica ie se pot acoperi mai multe tipuri de activită i didactice (reactualizarea cunoştin elor, diagnosticul evaluării, evaluarea formativă, feedback-ul). Ceea ce am descoperit a fost folosirea pozitivă a telefoanelor inteligente, în clasă, constatând că dăunător nu este faptul că elevii le folosesc, ci cât le folosesc şi în ce scop.

Observa iile noastre arată că, utilizând sistemul de răspuns Mentimeter în clasă, creşte învă area activă, elevii sunt mai angaja i în procesul cognitiv în timpul învă ării. Mentimeter este doar unul din aceste instrumente ce se poate adăuga ca alternativă la cele consacrate: Google Classroom, biblioteca digitală, tabla interactivă etc. Putem observa cum informatica pedagogică transformă şcoala şi modul de realizare mentală a unor opera ii fundamentale: cititul, scrisul, socotitul, transmiterea şi emiterea informa iei. Definită de Patrick Mendelsohn (1992) la „A treia întâlnire francofonă de didactică a informaticii”, informatica pedagogică este întâlnirea dintre o realitate psihologică, un subiect care înva ă, şi institu ională, cadrul şcolar, spre exemplu, cu o realitate tehnologică, computerul şi limbajele sale.

Demersul nostru se înscrie în cadrul conceptului de practica reflectivă, fiind menit ,să monitorizeze, evalueze şi să reconsidere, în mod continuu, propriile practici educa ionale" (Stăncescu, Drăghicescu \& Petrescu, 2018). Acest proces reflectiv ne-a făcut să constatăm că ,foarte adesea, elevii pe care noi încercăm să-i inspirăm sunt cei care sfârşesc prin a ne inspira." (Sean Junkins) $)^{3}$. Această experien ă pedagogică se înscrie în filozofia unei cercetări interdisciplinare care compară diferite tehnici de predare în diferite contexte sau situa ii. Se confirmă valabilitatea afima iei că, în şcoală, metoda devine lucrul de căpetenie (Mihai Eminescu), nefiind vorba de con inut, ci de 
abordarea acestuia. De asemenea, întrebarea este esen ială în lec ie, fiindcă aduce dialogul, activează elevul, transformându-l dintr-un public pasiv, în unul activ, capabil să interac ioneze, să ac ioneze, să gândească şi să rezolve probleme.

\section{Note}

1. Mihai Eminescu, „Timpul”, 9 august 1880, „D. Jules Ferry, ni se pare ...”

2. Mark Hersam, profesor dr. ing, Universitatea Northwestern, https:// stiintasitehnica.com/nanotehnologie-interviu-mark-hersam/

3. Sean Junkins, profesor, Whittemore Park Middle School, South Carolina, https://sjunkins.wordpress.com

\section{Referin e}

- Bloom, B.S. (1984). The 2 sigma problem: The search for methods of group instruction as effective as one-to-one tutoring. Educational Researcher, 13(6), 4-16. https://doi.org/10.2307/1175554.

- Bocoss, M. (2017). Didactica disciplinelor pedagogice. Un model constructivist. Piteşti: Editura Paralela 45.

- Bojinova, E., \& Oigara, J. (2013). Teaching and Learning with Clickers in Higher Education. International Journal of Teaching and Learning in Higher Education, 25(2), 154-165.

- Bruff, D. (2009). Classroom response systems („Clickers”). Vanderbilt University. Published by Jossey-Bass

- Clarke, S.L. (2017). Three Interactive Polling Tools Reviewed. Disponibil la: http://sydney.edu.au/education-portofolio/ei/teacheing@sydney/author/scla7456/

- Constantinescu, R., \& Dănăilă, I. (2013). Instrumente online - Microsoft Outlook 2013. Bucureşti: Casa de Editură Euroaptitudini.

- Cristea, S. (2000). Dic ionar de pedagogie. Chişinău, Bucureşti: Grupul Editorial Litera. Litera Interna ional.

- Guthrie, R., \& Carlin, A. (2004). Waking the dead: Using interactive technology to engage passive listeners in the classroom. Proceedings of the $10^{\text {th }}$ Americas Conference on Information Systems, New York, NY.

- Johnson, J.T. (2005). Creating learner centered classrooms: Use of an audience response system in pediatric dentistry education. Journal of Dental Education, 69 (3). 
- Mendelsohn, P. (1992). L'ordinateur dans l'enseignment. Troisieme rencontre francophone de didactique de l'informatique, Jul 1992, Sion, Suisse. Disponibil la: https://edutice.archives-ouvertes.fr/edutice-00359178/document

- Neacşu, I. (2015). Metode şi tehnici de învă are eficientă. Fundamente şi practici de succes. Iaşi: Editura Polirom.

- Rudolph, J. (2018). A brief review of Mentimeter - A student response system. Journal of Applied Learning \& Teaching, 1(1). Disponibil la: http:// journals.sfu.ca/jalt/index.php/jalt/article/view/6/2

- Sandu, E. (2002). Literatură şi gramatică română-pentru gimnaziu şi examenul de capacitate. Iaşi: Editura Polirom.

- Stăncescu, I., Drăghicescu, L.M., \& Petrescu, A.M.A. (2018). Practica reflectivă a profesorului - o necesitate. Revista de pedagogie, 1, 93-109.

- https://www.mentimeter.com

The online version of this article can be found at: http://revped.ise.ro/category/2019-en/

\section{(cc) $\mathrm{BY}-\mathrm{NC}-\mathrm{SA}$}

This work is licensed under the Creative Commons Attribution-NonCommercial-ShareAlike 4.0 International License.

To view a copy of this license, visit http://creativecommons.org/licenses/by-nc-sa/4.0/ or send a letter to Creative Commons, PO Box 1866, Mountain View, CA 94042, USA.
Versiunea online a acestui articol poate fi găsită la: http://revped.ise.ro/category/2019-ro/

\section{$( c c ) \longdiv { B r - N C - S A }$}

Această lucrare este licen iată sub Creative Commons Attribution-NonCommercial-ShareAlike 4.0 International License.

Pentru a vedea o copie a acestei licen e, vizita $i$ http://creativecommons.org/licenses/by-nc-sa/4.0/ sau trimite i o scrisoare către Creative Commons, PO Box 1866, Mountain View, CA 94042, SUA. 